\title{
THE EFFECT OF POSTURE UPON THE COMPOSITION AND VOLUME OF THE BLOOD IN MAN ${ }^{1}$
}

\author{
BY WILLARD OWEN THOMPSON, ${ }^{2}$ PHEBE K. THOMPSON, ${ }^{3}$ AND MARY \\ ELIZABETH DAILEY
}

(From the Metabolism and Neurological Laboratories of the Massachusetts General Hospital)

(Received for publication January 18, 1928)

\section{INTRODUCTION}

About one year ago, Lindhard (2) reported a few observations on the distribution in the blood stream of vital red injected intravenously. He found that in man, in the sitting position, after a mixing time of 5 minutes, blood from the saphenous vein contained dye in a concentration one-half of that in blood taken from the cubital vein. If, however, the man walked between the time of dye injection and the time of blood collection, the concentration of dye in blood from the two veins was the same. He concluded that, in order to get accurate observations of plasma volume, the subject should walk between the time of dye injection and blood collection. Numerous observations of plasma volume had previously been made by one of us (3) (42) by means of the so-called dye method, in which a similar dye, brilliant vital red, was used. These had already led to the conclusion that, when observations are made exclusively upon blood from an arm vein in a normal man in the horizontal position after a rest period of at least 30 minutes, similar results are always obtained. The contrast between Lindhard's observations and our own made it appear desirable to determine conclusively the effect of posture on plasma volume determinations by the dye method.

Early in our work, we observed that in an individual in the standing still position, the volume of cells per liter of blood, the red count and

${ }^{1}$ A brief account of this work has already been published (1).

2 Fellow of the National Research Council. Research Fellow in Medicine, Harvard Medical School and Massachusetts General Hospital.

${ }^{3}$ Research Fellow in Medicine, Massachusetts General Hospital. 
the concentration of dye in arm venous blood were greater than in the recumbent position. It, therefore, appeared highly probable that standing still produced a diminution in the total amount of plasma. The study of the effect of posture on the composition of the blood thus became a second important part of our investigation.

Böhme, in 1911 (4), made several observations, at short intervals, of the refractive index of the serum of ear blood in a man lying down just after walking about. He found that it steadily decreased for about 30 minutes, when a resting level was reached. The change often corresponded to a variation in serum protein of more than 12 per cent. This change was also observed in several individuals when they lay down at the end of a day's work. He also found that the protein concentration was about 5 to 6 per cent greater when the subjects were in the sitting position than when they were lying down.

Cipriani and Moracchini (5) have recently reported determinations of the serum protein on cardiac and nephritic patients of various types by the refractometric method. Blood for the determinations was withdrawn in the morning both before and 4 hours after arising. The patients received no food or water until after the completion of the experiments. In 9 out of 11, an increase in serum protein of 7 to 15 per cent was observed. Two normal persons showed no change under the same conditions. During a control period of 4 hours in bed, no change in the value of serum protein was observed in either the normal or the pathological cases.

We have not found any observations on the effect of standing still on the composition of the blood. It was, however, known to us from the work of Field and Bock (6) that, in this position, marked changes in the circulation may occur.

\section{METHODS}

The subjects took no food or liquid after 6 p.m. the day before the experiment. All experiments were preceded by a period of at least 30 minutes in the horizontal position. When taking the standing still position, the subjects were asked to stand with the feet about six inches apart and to remain as motionless as possible. In spite of good intentions, they could not avoid slight movements.

Plasma volumes were determined by the dye method of Keith, Rowntree and Geraghty (7) except that brilliant vital red (1.5 per cent solution) was used instead of vital red, and 1.6 per cent sodium oxalate $(2 \mathrm{cc}$. to about $10 \mathrm{cc}$. of blood) 
was used instead of powdered sodium oxalate as an anticoagulant. Unless otherwise stated in the tables, the dye was invariably injected into an arm vein (usually the right cubital).

The same sample of blood, collected in calibrated $15 \mathrm{cc}$. centrifuge tubes, and spun at 2500 revolutions per minute for at leas $\mathbf{4 5}$ minutes, served for the estimation of relative cell and plasma volume and also for total plasma volume. Red counts were also made on this sample of blood.

For all other determinations, coagulation was prevented by the use of powdered potassium oxalate,- -about $20 \mathrm{mgm}$. to $10 \mathrm{cc}$. of blood.

Total nitrogen was determined by the Dyer modification (8) of the macroKjehldahl method using $2 \mathrm{cc}$. of plasma. The non-protein nitrogen was determined by the Folin-Wu method (9).

Total plasma protein was estimated by subtracting the non-protein nitrogen from the total nitrogen and multiplying the difference by 6.25 .

Plasma water was determined by drying a known amount of plasma to a constant weight in an electric oven at a temperature of $110^{\circ} \mathrm{C}$.

Specific gravities were done for us by Miss Dorothy Sloane in the surgical research laboratory, using the method of Barbour and Hamilton (10).

Total $\mathrm{CO}_{2}$ determinations were made for us in Dr. Arlie V. Bock's laboratory using Van Slyke's method (11).

Chlorides were determined by Van Slyke's method (12).

All of these determinations were made on samples of blood drawn from a cubital vein with the arm, held at the side. Additional measurements of total plasma volume, red count and cell volume were also frequently made on blood drawn from a foot vein. For all determinations other than red count, cell volume and total plasma volume, the blood was collected under oil before injecting the dye.

THE SUBJECTS STUDIED

Cases 2, 7 and 8 were normal individuals.

Cases 1, 3, 4 and 5 were cured cases of exophthalmic goitre. Case 1 had slight pitting edema of the ankles. This was probably cardiac in origin but there were no other cardiac symptoms.

Case 6 was a case of myxedema whose metabolism was held at a normal level for 16 months previous to and also during the experimental period.

Case 9 had untreated myxedema.

\section{EXPERTMENTAL RESULTS}

In table 1 the average values and in tables 2 to 4 the detailed figures are given for the nine individuals studied in the horizontal and in the standing still positions. 
It may be seen that, during the period of standing still, after a rest in the recumbent position, there are the following changes in the blood:

1. An increase in the number of red cells per cubic millimeter of blood (column I).

2. A corresponding increase in the volume of cells per liter of blood (column II).

3. An increase in the specific gravity of plasma (column VI).

4. An increase in the concentration of plasma protein (column IV).

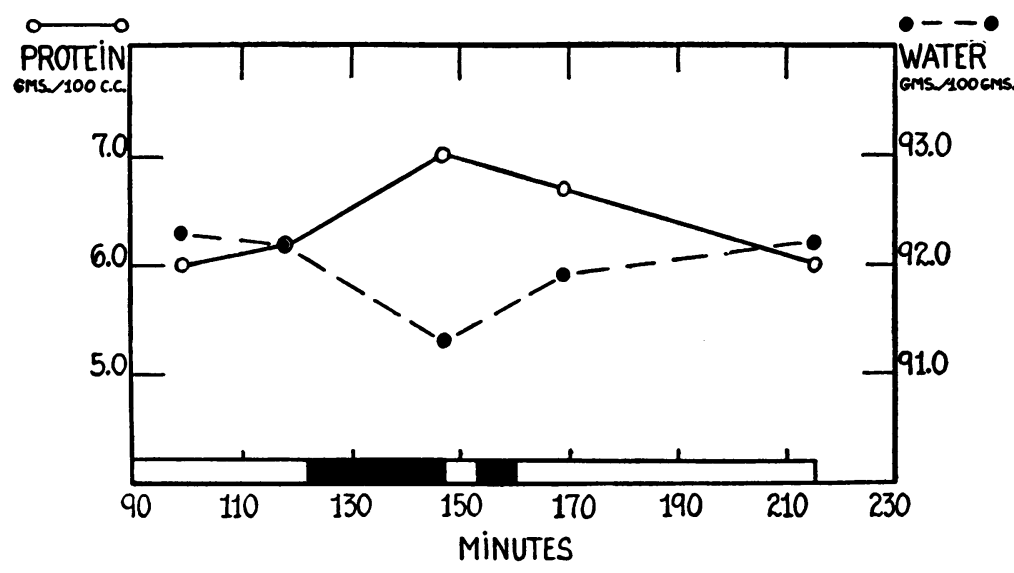

Fig. 1. Variations in the Concentration of Plasma Protein and Plasma

Water Accompanying Change from the Recumbent to the Standing

Still Postrion Followed by the Reverse Change (Case 7; Table 4)

White areas denote the recumbent position, and black areas, the standing still position.

5. A decrease in the concentration of plasma water (column V).

6. A decrease in the total amount of plasma in the blood of the whole body (column III).

Upon resuming the recumbent position the changes are reversed (table 4). Data on a typical case are plotted in figure 1.

From these observations, it seems safe to draw the conclusion that, while standing still, the blood temporarily loses a much greater volume of fluid than it gains. 


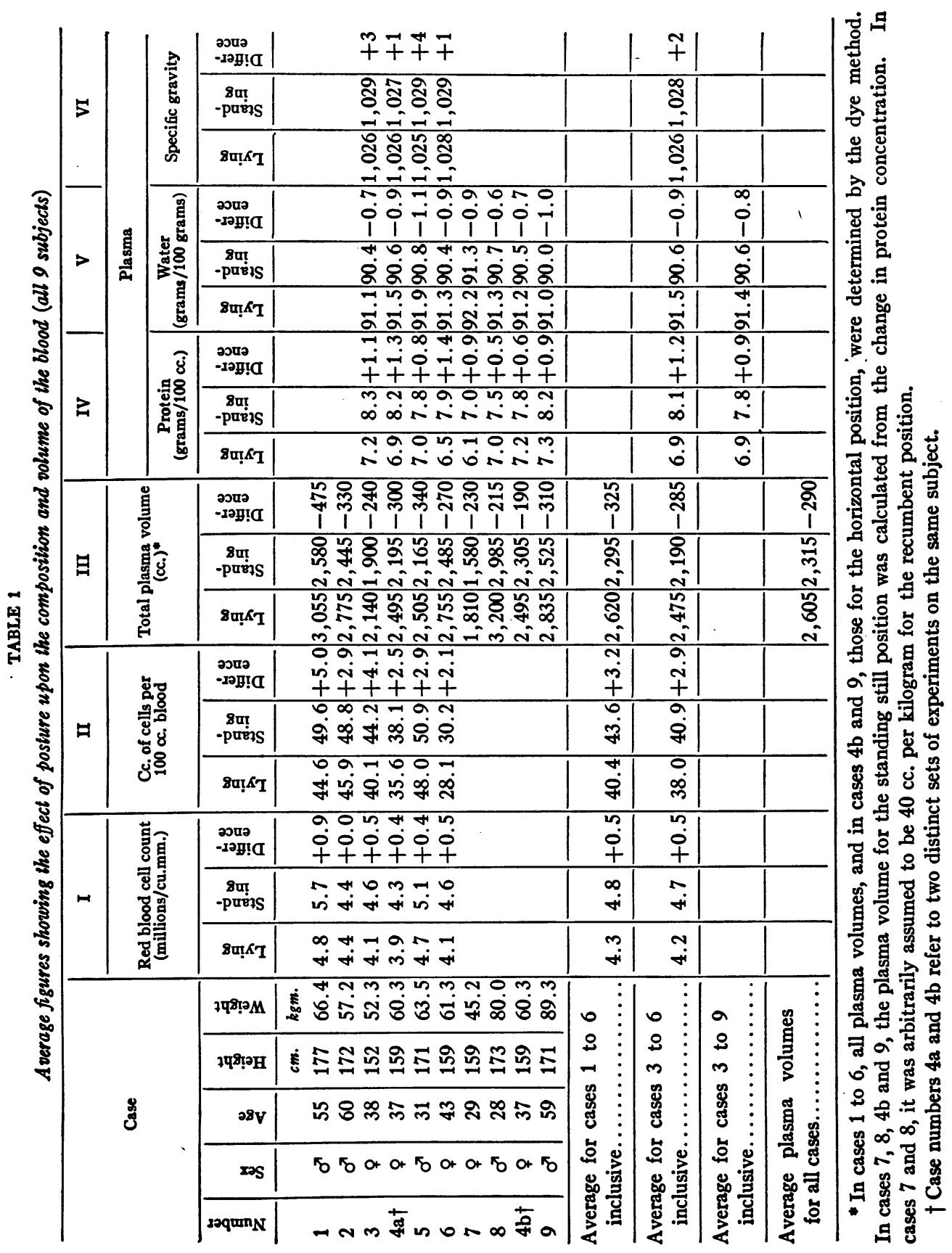



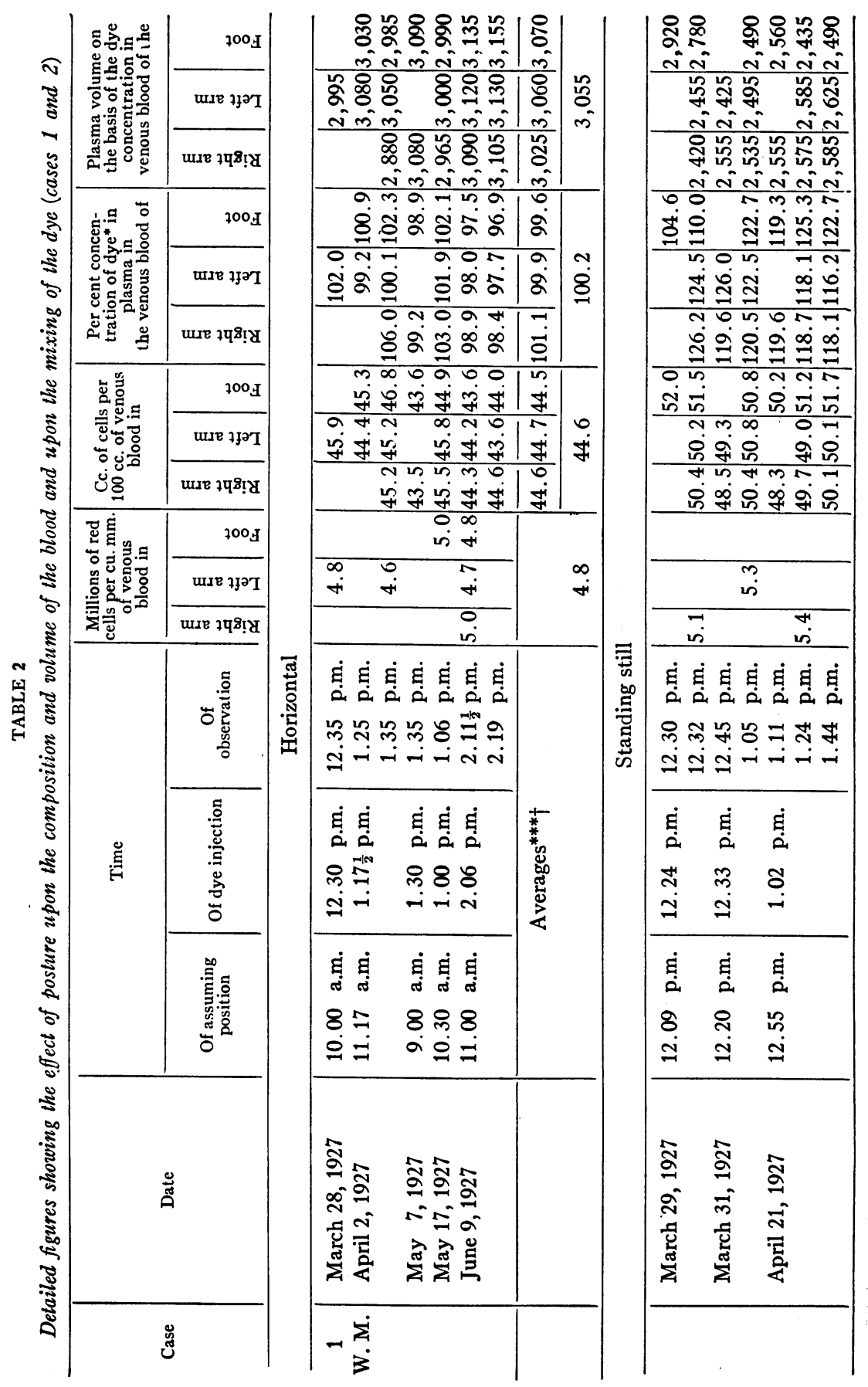


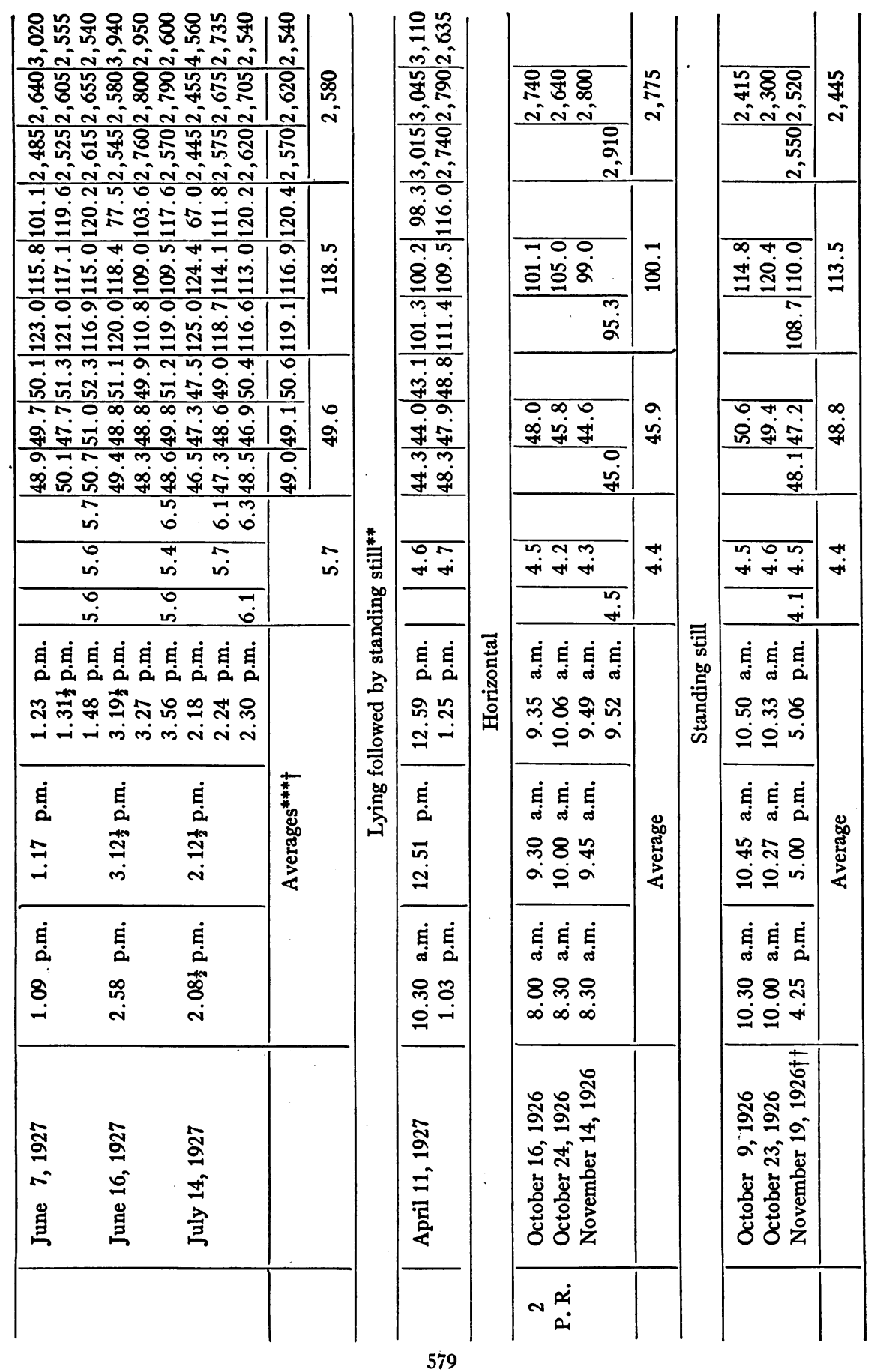




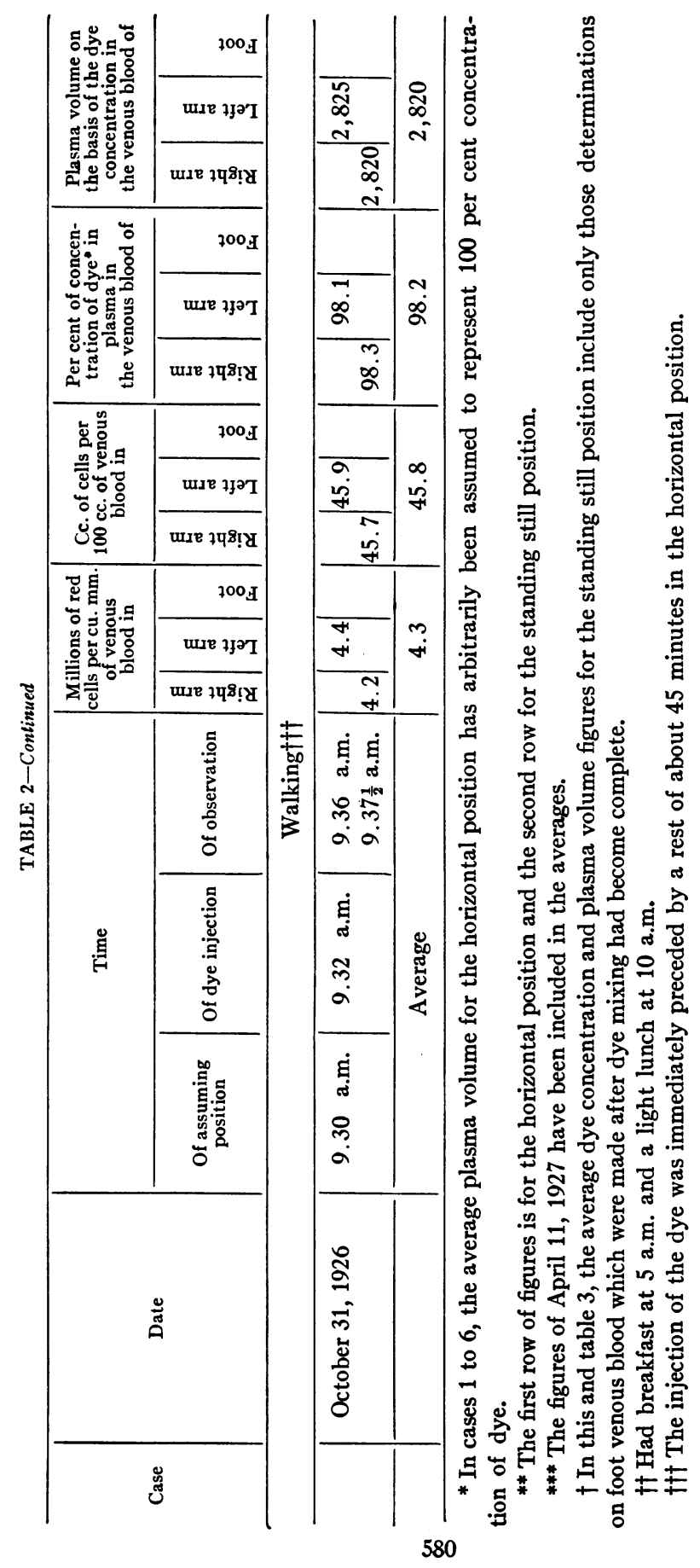


Interrelation of the various manifestations of the plasma volume reduction

Assuming that the fluid lost from plasma in a subject in the standing still position is protein free, the changes in red count, plasma protein and plasma water calculated from the changes in total plasma volume correspond well with the actual observations (table 5). Moreover, the total cell volume for each subject, calculated from the total plasma

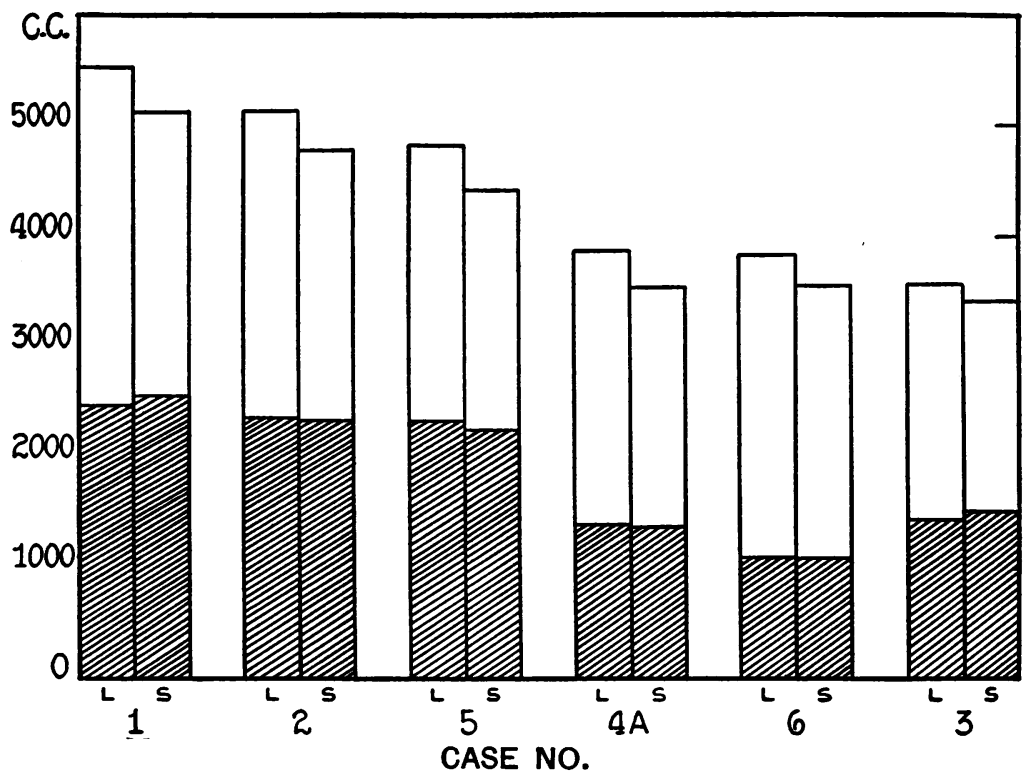

Fig. 2. The Constancy of the Total Cell Volume in the Recumbent and Standing Still Positions (Table 6)

Cross-hatched areas denote total cell volume, and white areas, total plasma volume. " $L$ " denotes the recumbent and " $S$ " the standing still position.

volume and the cell percentage, is the same in both the recumbent and standing still positions (table 6, figure 2).

The reciprocal relation between the protein and water changes is shown in figure 3.

These facts are consistent with the hypothesis that there has been, on the average, a net loss of $110 \mathrm{cc}$. of a protein free fluid per liter of plasma, or a total loss of $290 \mathrm{cc}$., (table 1, column III), and no other change. 

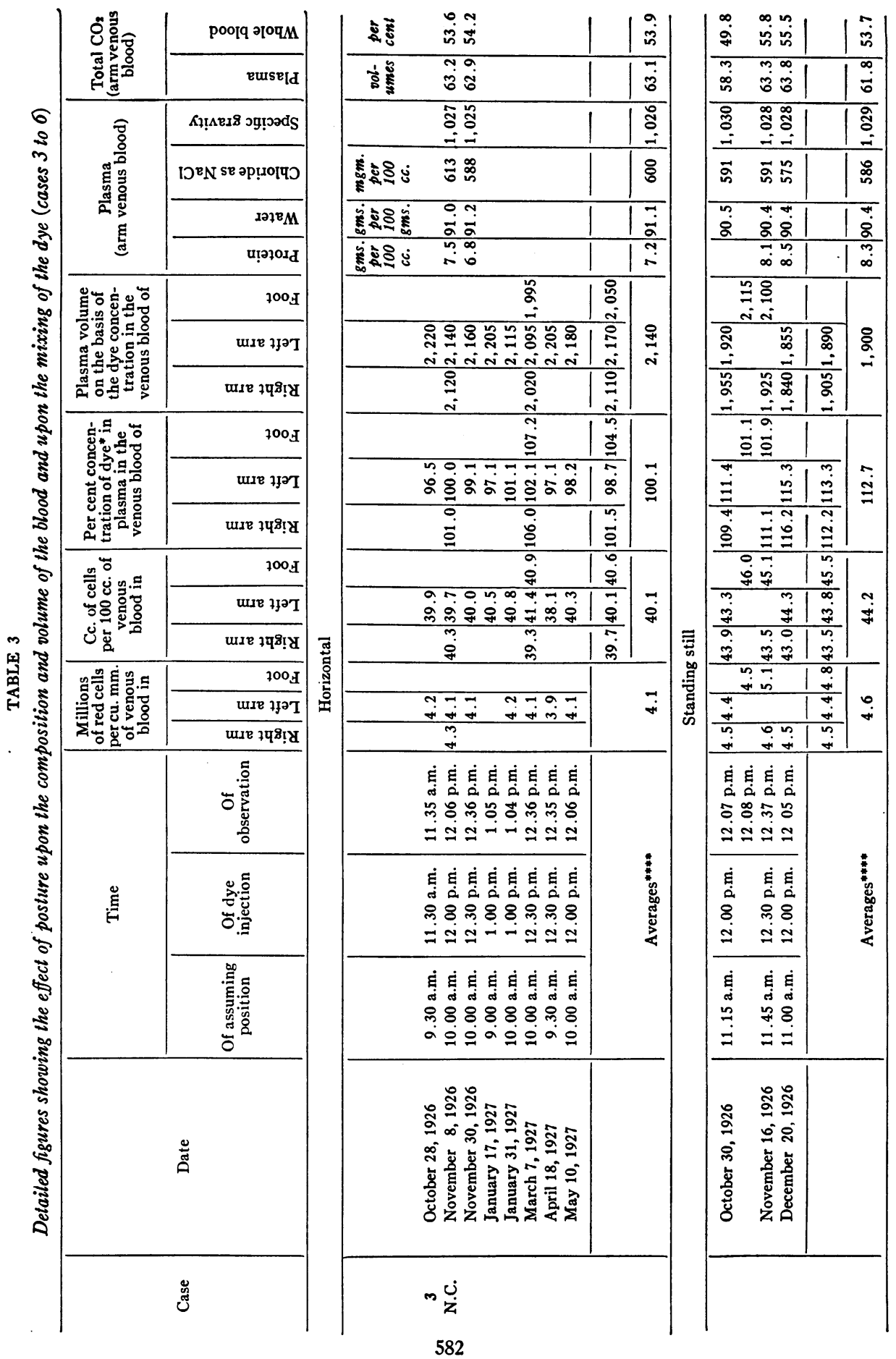


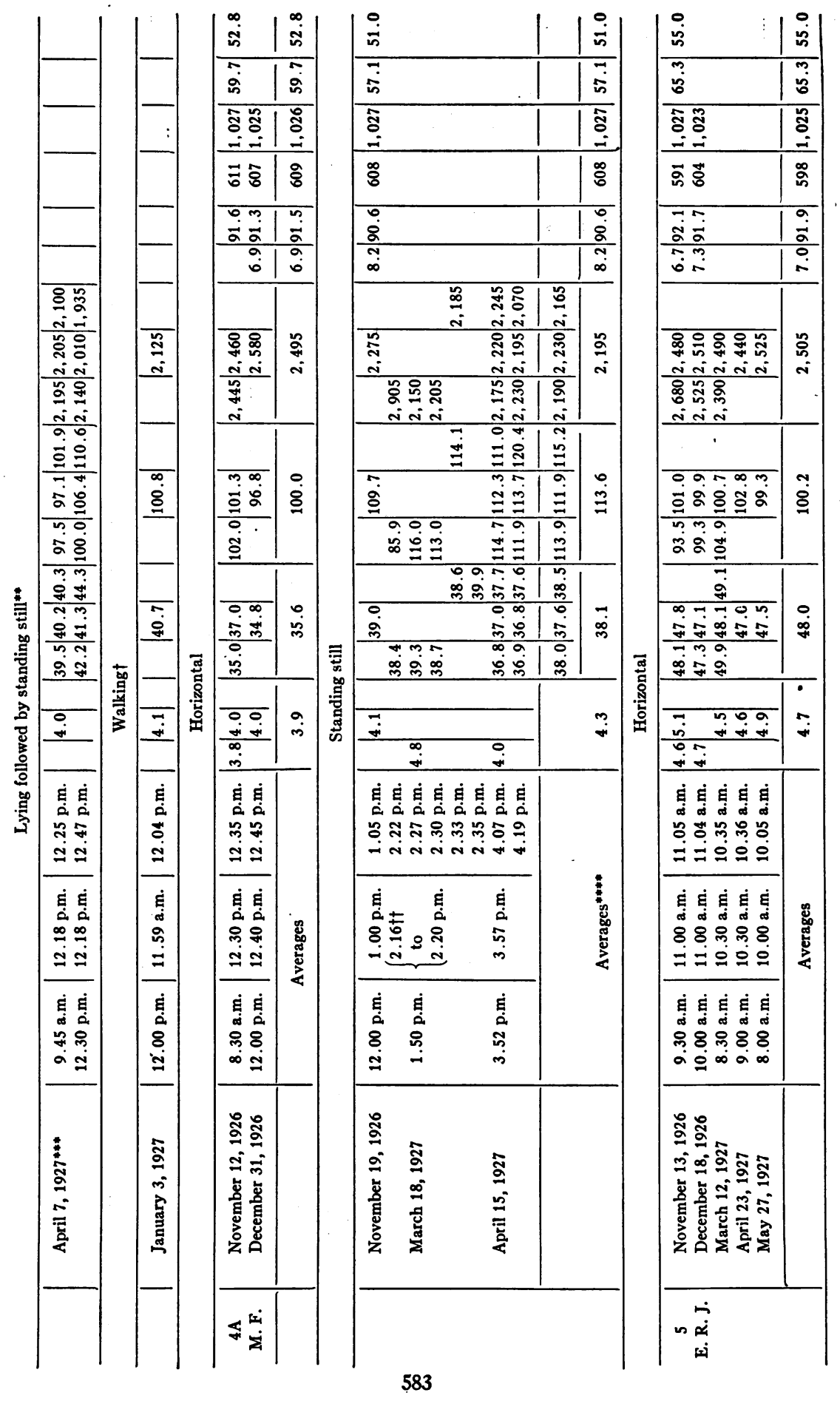




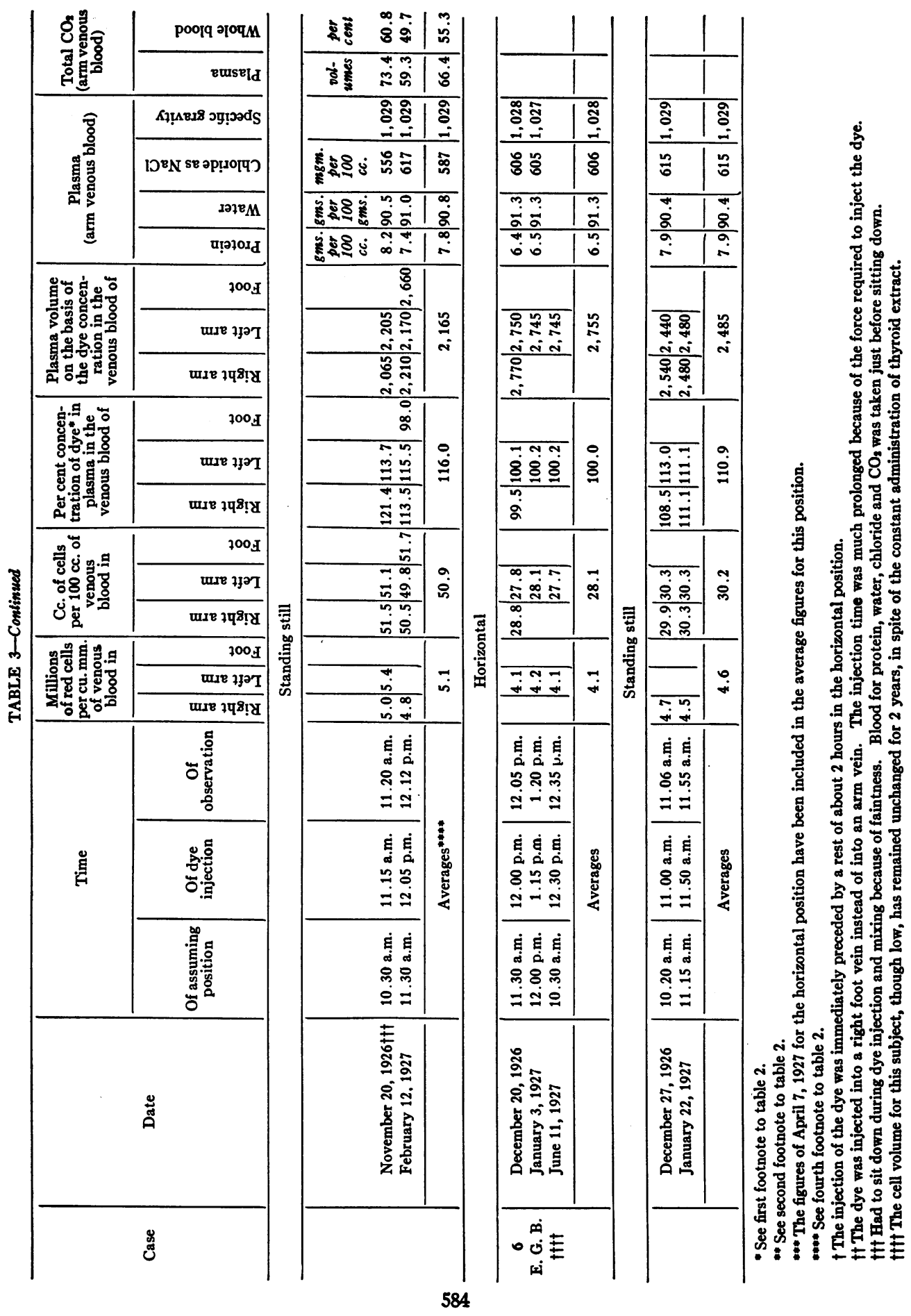


- It is of interest that L. J. Henderson (13) has recently calculated that the concentration changes in exercise reported by Bock et al. (14) could be accounted for by the removal from blood of $50 \mathrm{cc}$. per liter of a fluid of the composition of lymph (protein-free) and the addition to it of $25 \mathrm{cc}$. of cells per liter. A loss of $50 \mathrm{cc}$. of fluid per liter of blood is roughly equal to a loss of 90 to $100 \mathrm{cc}$. per liter of plasma. Thus it would appear that the blood loses approximately the same amount and type of fluid when a subject exercises as when he stands still.

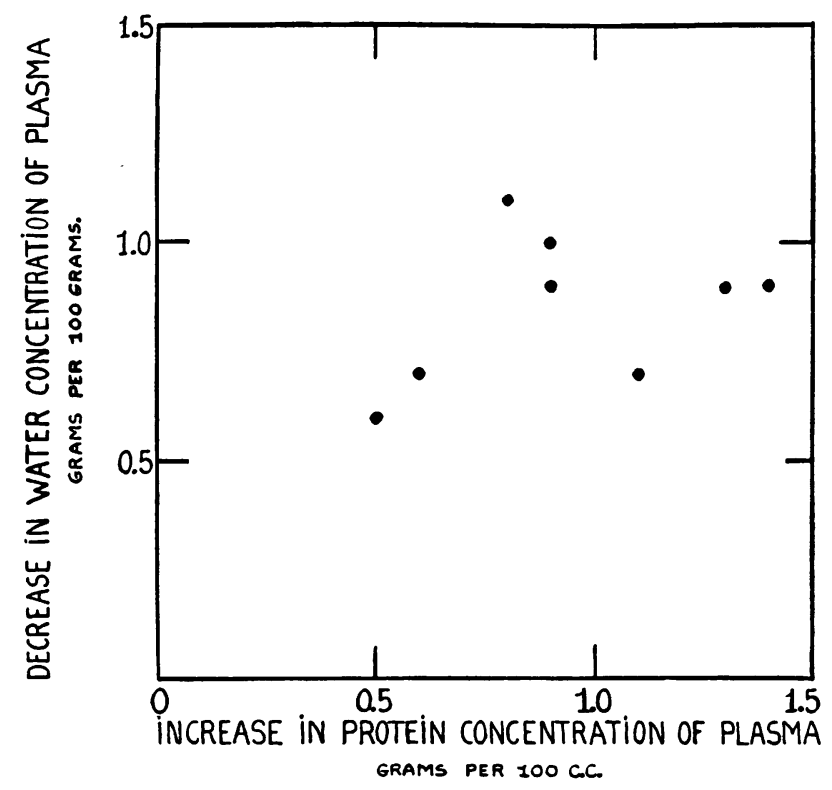

Fig. 3. Increase in Plasma Protein Concentration and Decrease in

Piasma Water Concentration Accompanying Change from the Recumbent to the Standing Still Position (Table 1)

The rate at which the loss of plasma water occurs

The data on cases $1,4 \mathrm{~b}$, and 9 indicate that the concentration changes reach a maximum after standing still 20 to 30 minutes. The data on case 1 are especially interesting in this respect. Numerous observations on this case during a period of 3 months yield uniform measurements of cell volume in both arm and foot venous blood in the horizontal position. On the same individual many other observations 


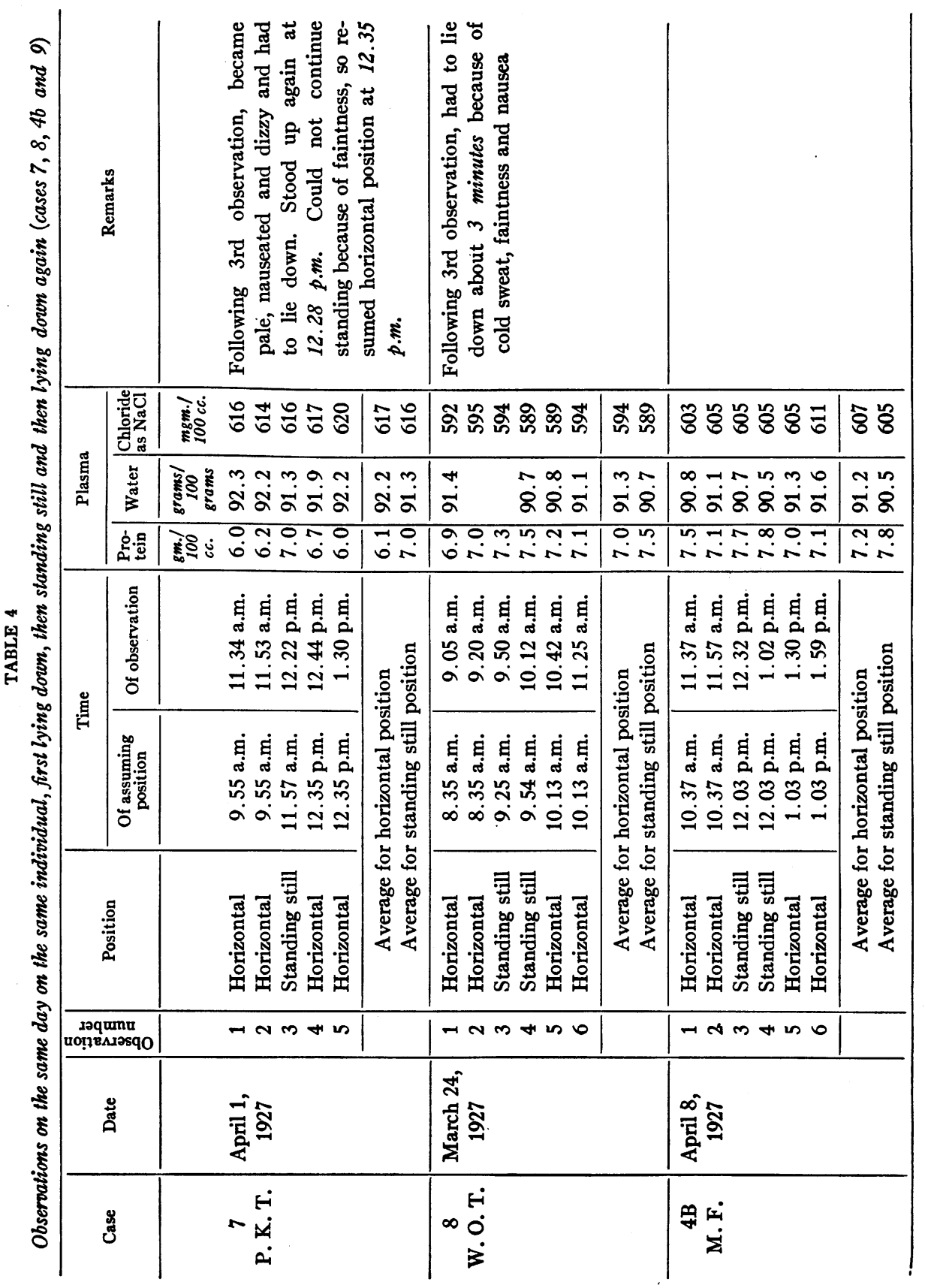




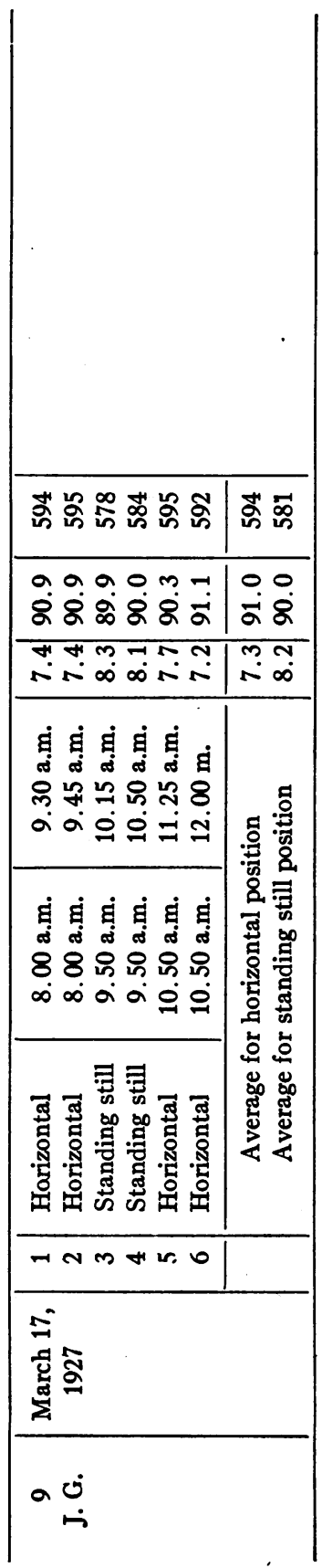


were made at different times after standing still. These are plotted in figure 4. Several measurements of cell volume have also been made on this subject on the same day at different intervals after assuming the standing still position. These are plotted in figure 5. It will be observed that, on standing still, there is a rapid increase during about 20 minutes, after which the rate of increase diminishes up to about 30 minutes, when a level is reached. This curve is of the type to be expected and, except that the increase occurs much more slowly,

TABLE 5

Comparison of the values observed for the red count, plasma protein and plasma water with those calculated from the changes in total plasma volume

\begin{tabular}{|c|c|c|c|c|c|c|c|c|c|}
\hline \multirow[b]{2}{*}{ Case } & \multicolumn{3}{|c|}{$\begin{array}{l}\text { Average red count for the } \\
\text { standing still position }\end{array}$} & \multicolumn{3}{|c|}{$\begin{array}{l}\text { Average plasma protein for } \\
\text { the standing still position }\end{array}$} & \multicolumn{3}{|c|}{$\begin{array}{l}\text { Average plasma water for } \\
\text { the standing still position }\end{array}$} \\
\hline & Observed & \begin{tabular}{|c} 
Calcu- \\
lated \\
from \\
change \\
in total \\
blood \\
volume
\end{tabular} & $\begin{array}{l}\text { Ratio- } \\
\text { ob- } \\
\text { served/ } \\
\text { calculated }\end{array}$ & Observed & $\begin{array}{l}\text { Calcu- } \\
\text { lated } \\
\text { from } \\
\text { change } \\
\text { in } \\
\text { plasma } \\
\text { volume }\end{array}$ & $\begin{array}{l}\text { Ratio- } \\
\text { ob- } \\
\text { served/ } \\
\text { calculated }\end{array}$ & Observed & \begin{tabular}{|c} 
Calcul- \\
lated \\
from \\
change \\
in \\
plasma \\
volume
\end{tabular} & $\begin{array}{l}\text { Ratio- } \\
\text { ob- } \\
\text { served/ } \\
\text { calculated }\end{array}$ \\
\hline & $\begin{array}{c}\text { millions } \\
\text { per } \\
\text { cu.mm. }\end{array}$ & $\begin{array}{c}\text { millions } \\
\text { per } \\
\text { cu.mm. }\end{array}$ & & per cent & per cent & & per cent & per cent & \\
\hline 1 & 5.7 & 5.2 & 1.10 & & & & & & \\
\hline 2 & 4.4 & 4.7 & 0.94 & & & & & & \\
\hline 3 & 4.6 & 4.3 & 1.07 & 8.3 & 8.1 & 1.02 & 93.0 & 92.7 & 1.002 \\
\hline $4 a$ & 4.3 & 4.3 & 1.00 & 8.2 & 7.9 & 1.04 & 93.0 & 93.0 & 1.000 \\
\hline 5 & 5.1 & 5.1 & 1.00 & 7.8 & 8.1 & 0.96 & 93.4 & 93.3 & 1.001 \\
\hline 6 & 4.6 & 4.4 & 1.04 & 7.9 & 7.2 & 1.10 & 93.0 & 93.2 & 0.998 \\
\hline rerage & 4.8 & 4.7 & 1.025 & 8.1 & 7.8 & 1.03 & 93.1 & 93.1 & 1.000 \\
\hline
\end{tabular}

is similar to that reported by Böhme (4) for the increase in protein concentration during exercise.

There are insufficient data to determine when dilution of the blood becomes complete on reverting from the standing still to the horizontal position. In case 7 the plasma water had not reached its prestanding level within 9 minutes. In cases 8 and $4 \mathrm{~b}$, the plasma water had increased as much at the end of 25 to 30 minutes as at the end of an hour. In case 9 , however, the process appeared to be still incomplete at the end of 30 minutes but had reached or passed the prestanding level at the end of an hour. Since this subject had untreated myxe- 
dema, the data suggest that this slow dilution may have been due to a diminished rate of absorption of water from tissues. In such cases, blood flow is known to be slow (15).

Differences between the relative cell volume of arm and foot venous blood in the standing still position

A review of the data shows that in nearly every instance where samples of blood were simultaneously taken from both arms and a

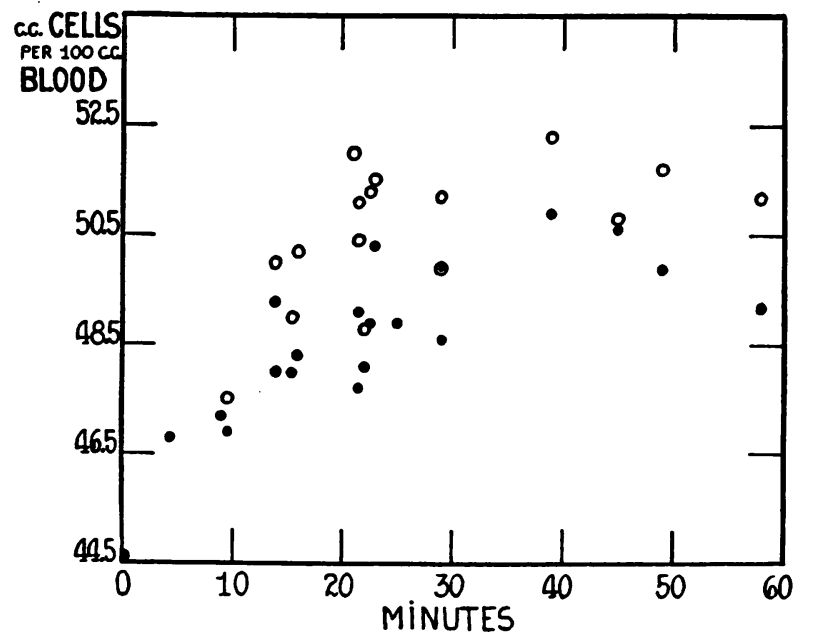

Fig. 4. The Rate at Which the Relative Cell Volume Increases on Changing from the Recumbent to the Standing Still Position (Case 1;

TABLE 2)

Three observations are included that are not recorded in the table. Average of observations on arm venous blood represented by dots. Observations on foot venous blood represented by circles.

foot when the subject was standing still, the relative cell volume was the same in the venous blood of the two arms, but greater in the vencus blood of the foot (table 7). In the horizontal posture, however, the volumes were the same in all three places.

Such variations may be due to:

1. Greater filtering off of fluid from the foot capillaries than from the capillaries of the hands and arms. 
2. A sedimentation of red blood cells in the blood vessels of the foot due to marked slowing of the circulation.

3. In part to greater $\mathrm{CO}_{2}$ content of foot venous blood than of arm venous blood resulting in swelling of the red blood corpuscles in the former.

The differences in $\mathrm{CO}_{2}$ content are certainly not great enough to produce the differences in cell volume observed. Therefore, the first two possibilities seem to be the most likely ones, and, of these, the first seems to be more probable than the second, although a combination of all three factors may be at work.

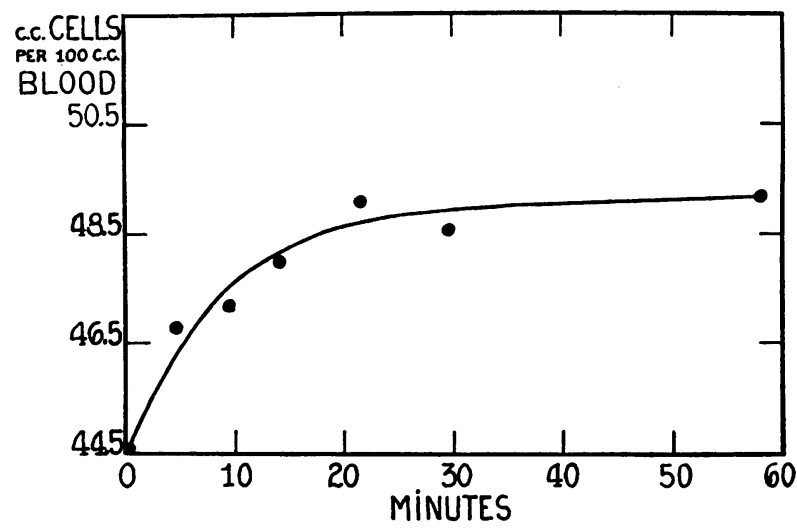

Fig. 5. The Rate at Which the Relative Cell Volume Increases on Changing from the Recumbent to the Standing Still Position (Arm Venous Blood OnLy)

All observations recorded were made on case 1 on the same day, in contrast to those in figure 4 which were made on different days over a period of months. Note that the rate at which the change occurs is about the same in both figures.

Along with the greater venous pressure in the foot in the standing still position (16) (17) (18), an actual increase in the filtering off of water from plasma in foot capillaries as compared with that in arm capillaries would be expected.

\section{Effect of posture on the mixing of the dye}

The more dilute the dye in any given sample of blood, the greater the plasma volume calculated therefrom. For the sake of convenience in interpreting the data, we have expressed the plasma volumes not 
only in cubic centimeters but also in percentages of dye concentration, arbitrarily taking the dye concentration corresponding to the average plasma volume for each subject in the horizontal position as a standard of comparison (100 per cent). Thus, for example, if (case 1) the average total plasma volume of $3055 \mathrm{cc}$., for the horizontal position,

TABLE 6

The total cell volume remains constant when the subject changes from the recumbent to the standing still position

\begin{tabular}{|c|c|c|c|c|c|c|c|c|c|c|c|}
\hline \multirow{2}{*}{ Case } & \multicolumn{2}{|c|}{$\begin{array}{l}\text { Cc. of cells per } \\
100 \mathrm{cc} \text { of blood }\end{array}$} & \multicolumn{3}{|c|}{$\begin{array}{l}\text { Total plasma volume } \\
\text { by dye method (cc.) }\end{array}$} & \multicolumn{3}{|c|}{$\begin{array}{l}\text { Calculated total blood } \\
\text { volume (cc.) }\end{array}$} & \multicolumn{3}{|c|}{$\begin{array}{l}\text { Total cell volume } \\
\text { (cc.) }\end{array}$} \\
\hline & Lying & $\begin{array}{l}\text { Stand- } \\
\text { ing }\end{array}$ & Lying & $\begin{array}{c}\text { Stand- } \\
\text { ing }\end{array}$ & $\begin{array}{c}\text { Differ- } \\
\text { ence }\end{array}$ & Lying & $\begin{array}{c}\text { Stand- } \\
\text { ing }\end{array}$ & $\begin{array}{c}\text { Differ- } \\
\text { ence }\end{array}$ & Lying & $\begin{array}{c}\text { Stand- } \\
\text { ing }\end{array}$ & $\begin{array}{l}\text { Differ- } \\
\text { ence }\end{array}$ \\
\hline 1 & 44.6 & 49.6 & 3,055 & 2,580 & -475 & 5,520 & 5,120 & -400 & 2,465 & 2,540 & +75 \\
\hline 2 & 45.9 & 48.8 & 2,775 & 2,445 & -330 & 5,130 & 4,780 & -350 & 2,355 & 2,335 & -20 \\
\hline 3 & 40.1 & 44.2 & 2,140 & 1,900 & -240 & 3,575 & 3,405 & -170 & 1,430 & 1,505 & +75 \\
\hline $4 a$ & 35.6 & 38.1 & 2,495 & 2,195 & -300 & 3,880 & 3,550 & -330 & 1,385 & 1,355 & -30 \\
\hline 5 & 48.0 & 50.9 & 2,505 & 2,165 & -340 & 4,820 & 4,410 & -410 & 2,315 & 2,245 & -70 \\
\hline 6 & 28.1 & 30.2 & 2,755 & 2,485 & -270 & 3,835 & 3,560 & -275 & 1,080 & 1,075 & -5 \\
\hline \multicolumn{5}{|c|}{ Average. } & -325 & & & -320 & & & +5 \\
\hline
\end{tabular}

TABLE 7

The effect of posture upon the volume of cells in blood simultaneously withdrawn from right arm, left arm and foot veins

\begin{tabular}{c|c|c|c|c|c|c}
\hline \multirow{2}{*}{ Case number } & \multicolumn{5}{|c}{ Cc. of cells per 100 cc. of venous blood } \\
\cline { 2 - 7 } & \multicolumn{3}{|c|}{ Lying down } & \multicolumn{3}{c}{ Standing still } \\
\cline { 2 - 7 } & Right arm & Left arm & Foot & Right arm & Left arm & Foot \\
\hline \multirow{2}{*}{1} & 44.6 & 44.7 & 44.5 & 49.0 & 49.1 & 50.6 \\
3 & 39.4 & 40.8 & 40.6 & 43.5 & 43.8 & 45.5 \\
5 & 49.9 & 48.1 & 49.1 & 50.5 & 49.8 & 51.7 \\
\hline Average...... & 44.6 & 44.5 & 44.7 & 47.7 & 47.6 & 49.3 \\
\hline
\end{tabular}

be assumed to correspond to 100 per cent dye concentration, then obviously a plasma volume of $2580 \mathrm{cc}$. (the average volume for the standing still position) corresponds to a dye concentration of $\left(\frac{100 \times 3055}{2580}\right)$ per cent $=118.3$ per cent. 
The dye mixing data on cases 1,3 and 5 (particularly case 1) show two significant things:

1. A much longer time is required for the dye concentration in the blood to become uniform all over the body in the standing still position than in the recumbent position. ${ }^{4}$

2. When the concentration has become uniform, it is greater in the standing still position than in the recumbent position.

Most of the delay in mixing in the standing still position appears to be due to a marked slowing of the circulation in the lower extremities. It may be seen from the data on cases 1 and 3 (table 2, e.g., experiment of June 9, 1927 on case 1) that, after a mixing time of 5 to 6 minutes, the dye concentration was the same in the venous blood of the right arm, of the left arm and of a foot when the subject was in the recumbent position. Complete mixing of the dye with the blood may, therefore, be fairly assumed at this time. ${ }^{5}$ In the standing still position, however, a different situation exists. As cases 1, 3 and 5 show (particularly case 1, table 2, e.g., experiment of July 14, 1927) $5 \frac{1}{2}$ to 8 minutes after injection, the dye concentration in foot venous blood was invariably less than in arm venous blood although the concentration in both arms was the same. After a time, which in case 1 varied from 9 to $14 \frac{1}{2}$ minutes, the dye concentration in the foot slowly increased until it became the same as in the arms or even slightly greater. ${ }^{6}$ Curiously enough, however, the concentration in the arms, in the meantime, did not decrease or decreased only slightly. This observation has since been corroborated

${ }^{4}$ It has also been shown that a much longer time elapses in the standing still than in the recumbent position, before dye injected into an arm vein appears in a foot vein and vice versa (19).

${ }^{5}$ It should be emphasized that 5-6 minutes does not necessarily represent the minimum time required for mixing to become complete when the subject is in the horizontal position.

${ }^{6}$ Thus, in case 1 , it took at least 2-3 times longer in the standing still than in the recumbent position for the dye concentration in the feet to become as great as that in the arms. Judging from the average figures of Turner (20) and of Field and Bock (6), the cardiac output in this case was probably reduced 20-50 per cent. Thus the slowing of the circulation in the lower extremities in the standing still position is probably not exclusively due to the reduced output of the heart. 
by several observations on another subject. It appears to represent a definite phenomenon the explanation of which is at present obscure.

The greater dye concentration in the standing still position after complete mixing is illustrated by numerous experiments on different days on case 1 (tables 2 and 8) and a smaller number on case 3 . The experiment in which samples were taken on subject 1 in the recumbent and then in the standing still position on the same day, after a single dye injection, is further proof of the same phenomenon. ,On April 11, 1927 , after the subject had remained two hours in the recumbent position, dye was injected in a right arm vein as usual and 8 minutes thereafter, venous blood samples taken simultaneously from right arm, left arm and left foot. In all three samples, the dye concentration was the same. The man then began standing still. Twenty-two

TABLE 8

Effect of posture upon the concentration of intravenously injected brilliant vital red (case 1)

\begin{tabular}{|c|c|c|c|}
\hline \multirow{2}{*}{ Position of body } & \multicolumn{3}{|c|}{$\begin{array}{l}\text { Average concentration of dye in plasma after } \\
\text { complete mixing }\end{array}$} \\
\hline & $\begin{array}{r}\text { Right arm, } \\
\text { venous blood }\end{array}$ & $\begin{array}{c}\text { Left arm, } \\
\text { venous blood }\end{array}$ & $\begin{array}{c}\text { Foot, } \\
\text { venous blood }\end{array}$ \\
\hline Lying down $\ldots \ldots \ldots \ldots \ldots \ldots \ldots \ldots$ & 101 & 100 & 100 \\
\hline Standing still $\ldots \ldots \ldots \ldots \ldots \ldots \ldots \ldots \ldots$ & 119 & 117 & 120 \\
\hline
\end{tabular}

minutes later blood samples were taken from the same three veins. In all three, the dye concentration was approximately the same, but was definitely greater ( 9 to 18 per cent) than in the same veins when the subject was lying down. Associated with the increase in dye concentration, was an increase in relative cell volume. This increase in dye concentration could not have occurred unless some fluid had disappeared from plasma.

Another observation worthy of note is that after complete mixing in the standing still position, the dye concentration in foot venous blood often appears to be slightly greater than in arm venous blood, whereas it is the same in all three places in the horizontal position. This is shown by the experiments of April 11, April 21, June 7 and of July 14 on case 1 . The differences are not great and are within the error of the method. They are suggestive, however, and consistent with 
the hypothesis of a slightly greater filtering off of plasma water from the capillaries of the foot than from those of the arm.

If the subject walked during the time that elapsed between the moment of dye injection and that of collection of blood for the plasma volume observation, the concentration of dye in arm venous blood was the same as it was when the subject was in the recumbent position, provided the injection of the dye had been immediately preceded by a rest period in this position. (See experiment of October 31, 1926 on case 2, and of January 3, 1927 on case 3.) There is some reason to suppose, however, that, after a longer period of walking about, there may be a loss of water from the plasma (4). Therefore, since in the recumbent position, the circulation is least affected by gravity and the dye readily becomes uniformly distributed throughout the plasma, this position would appear to be the one of choice for blood volume and other comparative blood studies.

In all plasma volume observations, the rate at which dye disappears from the ciŕculation is very important. It might be supposed that, after mixing had become complete while the subject was in the standing still position, the amount of dye left in plasma would be appreciably less than that injected. For this reason it might appear that the observed plasma volume, while less than that for the horizontal position, would be higher than it really was. One of us (3) has noted, however, that after repeated plasma volume observations, within a short period of time on the same individual, the rate at which the dye leaves the circulation decreases markedly, contrary to Lindhard's observation. Thus, after an hour under these conditions, the dye may be just as concentrated as after 5 minutes and 1 week or 10 days after the last of a series of 3 or 4 plasma volume observations done within 1 or 2 days of one another, the plasma may still be well tinged with dye (not sufficiently, however, to cause an appreciable error in the method). Illustrations of the slow disappearance of dye from plasma following repeated dye injections, may be seen in the data of March 31, April 21, June 7 and June 16 on case 1 .

Following a single dye injection, or a month or longer after repeated injections, however, the dye leaves the circulation at a more rapid rate so that dye disappearance may mask the volume reduction which occurs in the standing still position. This was probably the case in the 
lying-followed-by-standing experiment of April 7, 1927 on case 3. This was similar to the experiment of April 11,1927 on case 1 described above. One month had elapsed, however, since any observations had been made on the subject. Thus, while the cell volume rose when the standing still position was assumed, after complete dye mixing had occurred in the recumbent position, the dye concentration remained about the same or increased only slightly.

\section{Total $\mathrm{CO}_{2}$}

Total $\mathrm{CO}_{2}$ determinations were made on plasma and whole blood in a few cases. They showed no significant variations-except in case 5 on November 20, 1926 when, just preceding an attack of syncope in the standing still position, there was a well marked rise in $\mathrm{CO}_{2}$ with a proportional drop in chloride.

\section{Chlorides}

The chlorides were irregular, no significant change being recorded except the one just noted.

\section{DISCUSSION}

In an effort to elaborate their significance, our findings are correlated with some of those in the literature which have a bearing on this subject.

\section{Evidence to show that in the standing still position blood collects in} dependent portions of the body

Piorry (21) in 1826 was one of the first to comment on the marked impediment to the circulation in the erect posture. He attributed this to the influence of gravity and stated that it is due to this cause that the veins and capillaries of the hands become filled if the arms are held down. For the same reason varices and varicoceles enlarge when a person stands, and diminish when he lies down, and the head and face become red when held down. He opposed Bichat's teaching that in syncope the heart's activity is suspended, claiming that the heart continues to beat but that the beats have not force enough to overcome the effect of gravity. "It is not marvelous. It is simple. 
There is no doubt that it is the absence or presence of blood in the vessels of the brain that causes or dispels syncope." Piorry corroborated his hypothesis by showing that the horizontal position immediately restored consciousness in humans who had fainted and in dogs who had been bled in the "vertical feet down" position until syncope supervened.

Salathe (22) in 1877 made the significant observation that centrifugal force was just as effective in causing the death of rabbits as the "vertical feet down" position.

The influence of gravity on the distribution of blood is well shown by the simple experiment of Stephens (23) in 1904. In 21 healthy male medical students, he not only found that the systolic pressure in the radial arteries invariably dropped on changing from the horizontal to the upright position but also observed that in the lateral position the radial artery pressure in the arm which was uppermost was always decidedly less.

In 1895 Leonard Hill (24) reported that in cats, dogs and monkeys in the "vertical feet down" position the pressures in the femoral artery and vein rose while the carotid artery and jugular vein pressures fell markedly. The reverse effects were observed in the "vertical head down" position.

Through the open chest wall of an animal in the "vertical feet down" position, he frequently observed complete emptying of the heart, particularly if the splanchnics had been eliminated. This was accompanied by a fall in intracranial pressure, a marked drop in systolic pressure in the carotid, and finally by the cessation of respirations and of the pulse and by the apparent death of the animal. The heart continued to contract rhythmically. "On turning the animal to the horizontal position, the heart is seen to fill again immediately. The blood is actually shot out of the vena cava and from the veins of the splanchnic area into the heart."

Field and Bock (6) found that in 10 normal but non-athletic individuals "the average rate of blood flow (cardiac output) while sitting was 76 per cent and while standing 50 per cent of the rate while reclining. Inasmuch as the pulse rate increased from an average of 63 per minute in the reclining position to 65 per minute in the sitting position and 90 per minute in the standing position, the output per beat was tremendously diminished in the upright posture. 
Turner (20), using the same method on women, and Lindhard (25), Collett and Liljestrand (26) and Henderson and Haggard (27), using different methods, have reported findings which corroborate those of Field and Bock.

Although Salathe (22) in 1877 showed that rabbits died in the course of 15 minutes to 2 hours in the "vertical feet down" position, it remained for Churchill, Hurxthal and Miller (28) to prove that this was due to a markedly diminished cardiac output.

In view of the blood flow work just reported it is easy to understand the marked drop in pulse pressure (6) (20) (29) and in the pressure in the pulmonary artery (28) that occur in the motionless upright position.

The increase in venous and capillary pressures in dependent parts of the body in the standing still position

Associated with the collection of blood in dependent parts of the body when standing still there occurs an increase in venous pressure. This is obvious from the marked venous distension in the hand held down vertically or in the foot of a standing individual compared with the virtual collapse of such veins when held at heart level. The veins of the lower extremities in a subject standing still slowly become markedly engorged and the feet become cold and of a reddish blue color. No suction is required to withdraw blood from such a foot vein: the venous pressure squeezes the syringe piston out. On the contrary great difficulty is experienced even in puncturing the same vein when the subject is in the horizontal position, and, in many instances, once the vein is punctured the blood flows extremely slowly.

A similar observation was made by Leonard Hill (24). He noted that while a marked increase in venous pressure in the femoral vein occurred in animals in the "vertical feet down" position, the pressure became negative in the jugular vein and no blood would flow from a puncture hole. The reverse was true in the "vertical head down" position.

Recklinghausen (16) found that when the arm of a woman was held down vertically, the pressure in a hand vein was $40 \mathrm{~cm}$. of water as compared with a pressure of $10 \mathrm{~cm}$. of water when the arm was held at heart level. In a foot vein of the same woman the pressure was 62 
cm. of water in the sitting position and $79 \mathrm{~cm}$. of water in the standing position, pressures just about sufficient to support columns of blood reaching to the symphysis and not to the heart. Similar findings have been reported by Hooker (18) and by Carrier and Rehberg (17). The foot veins fill only slowly, however, in the erect posture and Recklinghausen states that he might perhaps have observed a further rise in venous pressure had he followed it over a long enough period. $\mathrm{He}$ was inclined to attribute the relatively small change in foot venous pressure as compared with arm venous pressure to a marked increase in vasomotor tone in the lower extremities in the erect posture causing the blood to trickle through very slowly to the venous side.

Resulting at least in part from the increased venous pressure in dependent parts of the body when a person stands still, there appears to be an increase in capillary pressure. Recklinghausen (16) showed that the capillary pressure was much greater in the foot of a standing woman and also in her hand when her arm was held down vertically than in the same parts of the body at heart level. The increase in capillary pressure in the foot, however, while absolutely greater, was relatively less than in the arm. Carrier and Rehberg (17), using a more accurate method, have shown that in the hand, the capillary pressure varies with the venous pressure. It is greatest when the hand is held down vertically and decreases until a level is reached as the hand is raised above the heart.

The marked increase in capillary pressure in the lower extremities of a person standing still, is obvious from a very simple experiment. A small needle prick which, in the skin of a foot of a person in the horizontal position, will occasion no bleeding, in the standing still position will cause oozing of blood for several minutes.

\section{Effect of increased venous pressure on the composition of the blood}

Cohnheim (30) was one of the first to show that, as a result of venous stasis due to application of a tourniquet, a fluid poor in protein passes very freely out of the capillaries into the tissues and from there into the lymph stream so that the small veins and capillaries became distended with erythrocytes. It has been shown that, under these circumstances, there is an increase in hemoglobin concentration, red count, specific gravity and in the dry weight of whole venous blood in 
the area distal to the tourniquet (31) (32). An increase in total plasma protein in the same area has been reported by several observers (4) (33) (34) (35) (36).

Drury and Jones (37) have recently shown, by plethysmographic studies, that edema is produced in the legs of healthy men as a result of raising the venous pressure by inflation of a blood pressure cuff. The rate of formation of edema appeared to depend upon the height to which the venous pressure was raised. Increase in volume due to increase in blood alone was allowed for.

It would seem inevitable that, when a person stands still, the capillary pressure should increase most in the lowermost parts of the body. The arterial pressure while dropping in the brachials and carotids in animals in the "vertical feet down" position increases in the femorals, both changes being due to gravity. Thus the capillary pressure in the legs is probably augmented from both the arterial and venous sides (the venous pressure being, of course, the more important) and the conditions favor the squeezing out of fluid from the plasma into the tissues.

From our observations, it is obvious that the fluid lost from plasma in the standing still position remains somewhere within the body. From the considerations just presented of the physical conditions involved, it would appear probable that most of it is collected as lymph in the lower extremities. This assumption is supported by the observation of Field and Bock (6). "We have noted that while a subject was standing during an experiment the calves of his legs became indurated and brawny and increased in circumference $1.5 \mathrm{~cm}$." It is also upheld by the work of Mosso (38). Using a delicate balance board, he found that when a subject assumed the horizontal position after standing for some time, the weight of the feet end of the board only very slowly decreased, in spite of the fact that presumably the excess blood leaves the lower extremities almost immediately.

\section{Cardiac edema and the reduction in plasma water}

The diminished amount of urine passed by a normal man in the standing still position as compared with the horizontal position (39) may perhaps be related to the relative anuria of the day and the polyuria of the night noted in cardiac decompensation. The collec- 
tion of ankle edema during the day and its disappearance during the night's rest in bed in the early stages of cardiac edema, may well be a related phenomenon. Cardiac decompensation is a condition in which numerous observers agree that there is a well marked increase in venous pressure (40) which subsides under treatment. A markedly reduced cardiac output has been shown by Meakins, Dautrebande and Fetter (41) to occur in mitral stenosis. This is probably the case in all decompensated cardiac patients. Thus, in contrast to conditions in normal man in the recumbent position, both normal man in the standing still position and the patient with cardiac edema in the recumbent position, appear to show diminished blood flow and increased venous pressure. In the one case, the increased venous pressure is due to venous congestion caused by gravity and, in the other, to venous congestion caused by a failing heart.

One of us has observed that in well marked cardiac edema there is an increase in plasma volume (42) and in this condition many workers have noted a decrease in concentration of plasma protein. The facts just presented, however, suggest that in the early stages of cardiac decompensation, when edema is present only in the ankles, a decrease in plasma water may occur.

Evolutionary significance of circulatory changes in the standing still position

The general nature of the response of the circulation to the motionless upright position appears to be the same in all mammals; but the degree of response seems to vary according to the habitual position of the animal. Those animals in which the trunk is normally supported horizontally appear to show a much poorer adaptation to the "vertical feet down" position than those in which the trunk is normally supported vertically. Thus Hill (24) found that in monkeys on changing from the horizontal to the "vertical feet down" position, the systolic pressure in the carotid artery fell much less than in cats, dogs and rabbits. He made the deduction that adaptation to the upright position was probably most complete in man.

Our observations and those of others clearly indicate, however, that even man's adaptation to this position is not complete and the maintenance of the standing still position for more than a few minutes is extremely difficult. 
The mechanism for adjustment to the standing still position appears to be an increase in vasoconstrictor tone in the dependent portions of the body (16) (24). This greatly diminishes the rate of blood flow to the venous side as manifested in our experiments by the slowness of the increase in dye concentration in foot veins. Flooding of the capillary reservoirs in the splanchnic area and lower extremities is thus prevented. Such a compensatory mechanism is only partially effective, however, for once the blood does succeed in getting through to the veins, it has difficulty in returning to the heart as manifested by the marked venous and capillary engorgement. In this way a vicious cycle is created. The blood flow is slowed not only as a result of the difficulty in returning blood to the heart but also by the compensatory mechanism itself.

Although the adjustment to the erect posture is very inadequate for standing still, it appears adequate for activity. In the movements of the daily routine, muscular contractions are constantly forcing blood back towards the heart. The intrapelvic rectal pressure, normally about 15 to $25 \mathrm{~mm}$. $\mathrm{Hg}$, may rise on very slight exertion, such as an arm or leg movement to 80 or $100 \mathrm{~mm}$. $\mathrm{Hg}$ and, if the movement is sudden, it may rise to $150 \mathrm{~mm}$. $\mathrm{Hg}$ (43). Slight leg movements may even force the blood from the feet into the chest, and thus prevent the ill effects of the motionless upright position. Under certain conditions, however, the compensatory mechanism may prove inadequate even during activity. Thus patients often faint when they first get out of bed after a long illness. This temporary loss of vasoconstrictor tone in the splanchnic area may represent a transient reversion (from disuse) to a more primitive state.

\section{SUMMARY AND CONCLUSIONS}

In the standing still position there occurs a net loss of approximately protein free fluid from the blood. This seems to be due chiefly to an increase in capillary pressure. The loss amounts on the average to about 11 per cent of the total plasma volume, and is probably greatest where the filtration pressure is most increased, namely, in the lower extremities.

The maximum fluid loss, which occurs in the standing still position 
in from 20 to 30 minutes, is made up in about the same time in the recumbent position.

Observations on the mixing time of a plasma volume dye show a marked prolongation of the time required for the concentration to become uniform in the blood all over the body in the standing still position. The same data suggest that the slowing of the circulation in the lower extremities in the standing still position is greater than that in other parts of the body.

The findings recorded show the importance of a rest period in the horizontal position for making blood volume and other comparative blood studies.

\section{BIBLIOGRAPHY}

1. Thompson, W. O., Thompson, P. K., and Dailey, M. E., Proc. of the Natl. Acad. of Sci., January, 1928. The Effect of Posture upon the Composition and Volume of the Blood in Man.

2. Lindhard, J., Am. J. Physiol., 1926, lxxvii, 669. A Dye Method for Determining the Blood Volume in Man.

3. Thompson, W. O., Unpublished data.

4. Böhme, A., Deut. Arch. f. klin. Med., 1911, ciii, 522. Utber die Schwankungen der Serumkonzentration beim gesunden Menschen.

5. Cipriani, C., and Moracchini, R., Minerva med., 1925, v, 261. Comportamento del siero di sangue e della diuresi nell'ortostatismo.

6. Field, H., Jr., and Bock, A. V., J. Clin. Invest., 1925, ii, 67. Orthopnea and the Effect of Posture upon the Rate of Blood Flow.

7. Keith, N. M., Rowntree, L. G., and Geraghty, J. T., Arch. Int. Med., 1915, xvi, 547. A Method for the Determination of Plasma and Blood Volume.

8. Dyer, B., J. of the Chem. Soc. (Transactions), 1895, lxvii, 811. Kjeldahl's Method for the Determination of Nitrogen.

9. Folin, O., and Wu, H., J. Biol. Chem., 1919, xxxviii, 81. A System of Blood Analysis.

10. Barbour, H. G., and Hamilton, W. F., J. Am. Med. Assoc., 1927, lxxxviii, 91. The Falling Drop Method for Determining Specific Gravity.

11. Van Slyke, D. D., and Neill, J. M., J. Biol. Chem., 1924, lxi, 523. The Determination of Gases in Blood and Other Solutions by Vacuum Extraction and Manometric Measurement. I.

12. Van Slyke, D. D., J. Biol. Chem., 1923-24, lviii, 523. The Determination of Chlorides in Blood and Tissues.

13. Henderson, L. J., Unpublished data.

14. Bock, A. V., Dill, D. B., Hurxthal, L. M., Lawrence, J. S., Coolidge, T. C., Dailey, M. E., and Henderson, L. J., J. Biol. Chem., 1927, lxxiii, 749. 
Blood as a Physico-chemical System. V. The Composition and Respiratory Exchanges of Normal Human Blood during Work.

15. Bock, A. V., and Field, H., Jr., Unpublished data.

16. Recklinghausen, H., Arch. f. Exper. Path., 1906, lv, 463. Unblutige Blutdruckmessung. III. Messung des Blutdrucks in den kleinen Arterien, Venen und Kapillaren des Menschen und beim Tier.

17. Carrier, E. B., and Rehberg, P. B., Quoted by Krogh, A. in "The Anatomy and Physiology of the Capillaries." Yale University Press, 1924, p. 222.

18. Hooker, D. R., Am. J. Physiol., 1911, xxviii, 235. The Effect of Exercise upon the Venous Blood Pressure.

19. Thompson, W. O., Alper, J. M., and Thompson, P. K., J. Clin. Invest., 1928, $\mathrm{v}, 605$. The Effect of Posture upon the Velocity of Blood Flow in Man.

20. Turner, A. H., Am. J. Physiol., 1927, lxxx, 601. The Circulatory Minute Volumes of Healthy Young Women in Reclining, Sitting and Standing Positions.

21. Piorry, P. A., Arch. gén. de. méd., 1826, xii, 527. Recherches sur l'influence de la pesanteur sur le cours du sang; diagnostic de la syncope et de l'apoplexie, cause et traitement de la syncope.

22. Salathé, A., Trav. du lab. de M. Marey. 1877, p. 251. De l'anémie et de la congestion cérébrales provoquées mecaniquement chez les animaux, par l'attitude verticale ou par un mouvement giratoire.

23. Stephens, O. Z., J. Am. Med. Assoc., 1904, xliii, 955. Blood Pressure and Pulse Rate as Influenced by Different Positions of the Body.

24. Hill, L., J. Physiol., 1895, xviii, 15. The Influence of the Force of Gravity on the Circulation of the Blood.

25. Lindhard, J., Skandin. Arch. f. Physiol., 1913, xxx, 395. Effect of Posture on the Output of the Heart.

26. Collett, M. E., and Liljestrand, G. Skandin. Arch. f. Physiol., 1924, xlv, 17. Variations in the Resting Minute Volume of the Heart in Man.

27. Henderson, Y., and Haggard, H. W., Am. J. Physiol., 1925, lxxiii, 193. The Circulation and its Measurement.

28. Churchill, E. W., Hurxthal, L. M., and Miller, D., Personal communication.

29. Sewall, H., Am. J. Med. Sci., 1919, clviii, 786. On the Clinical Significance of Postural Changes in the Blood-Pressures, and the Secondary Waves of Arterial Blood Pressure.

30. Cohnheim, J., Virchow's Archiv., 1867, xli, 220. Über venöse Stauung.

31. Grawitz, E., Ztschr. f. klin. Med., 1892, xxi, 459. Klinisch-experimentelle Blutuntersuchungen.

32. Schultz, W., and Wagner, G., Folia serolog., 1909, iii, 387. Über den Flüssigkeitsaustausch zwischen Blut und Geweben unter der Einwirkung von thermischen und anderen Einflüssen.

33. Kreibich, K., Folia Haematol., 1907, iv, 795. Über die refraktrometrischen Werte des Blutserums. 
34. Rowe, A. H., J. Lab. and Clin. Med., 1915-16, i, 485. The Effect of Venous Stasis on the Proteins of Human Blood Serum.

35. Peters, J. P., Bulger, H. A., Eisenman, A. J., and Carter, Lee, J. Biol. Chem., 1926, lxvii, 175. Total Acid Base Equilibrium of Plasma in Health and Disease. IV. The Effects of Stasis, Exercise, Hyperpnea and Anoxemia; and the Causes of Tetany.

36. Plass, E. D., and Rourke, M. D., J. Lab. and Clin. Med., 1927, xii, 735. The Effect of Venous Stasis on the Proteins of Blood Plasma and on the Rate of Sedimentation of the Red Blood Corpuscles.

37. Drury, A. N., and Jones, N. W., Heart, 1927, xiv, 55. Observations Upon the Rate at which Oedema Forms When the Veins of the Human Limb Are Congested.

38. Mosso, A., Arch. Ital. de Biol., 1884, v, 130. Application de la Balance à l'étude de la circulation du sang chez l'homme.

39. Erlanger, J., and Hooker, D. R., Jonhs Hopkins Hosp. Reports, 1904, xii, 145. An Experimental Study of Blood-Pressure and of Pulse Pressure in Man.

40. Eyster, J. A. E., Physiol. Rev., 1926, vi, 281. Venous Pressure and its Clinical Applications.

41. Meakins, J., Dautrebande, L., and Fetter, W. J., Heart, 1923, x, 153. The Influence of Circulatory Disturbances on the Gaseous Exchange of the Blood. IV. The Blood Gases and Circulation Rate in Cases of Mitral Stenosis.

42. Thompson, W. O., J. Clin. Invest., 1926, ii, 477. Studies in Blood Volume. I. The Blood Volume in Myxedema with a Comparison of Plasma Volume Changes in Myxedema and Cardiac Edema.

43. Keith, A., Brit. Med. J., 1923, i, 624. Hunterian Lectures on Man's Posture: Its Evolution and Disorders. 